\title{
Big Data for Individual Education: an angel or a
}

\section{monster?}

\author{
Yu Shuyu \\ College of Educational Technology \\ Northwest Normal University \\ Lanzhou, China \\ yu_shuyu@126.com
}

\author{
Ma Xiaoneng \\ College of Educational Technology \\ Northwest Normal University \\ Lanzhou, China \\ 824688931@qq.com
}

\author{
Jing Xin \\ School of Electronic Engineering \\ Xidian University \\ Xi'an, China \\ 489262138@qq.com
}

\begin{abstract}
The rapid de velopment of Information technology has brought the era of Big Data, a buzzword now familiar among most people, which has generated a huge influence on human social lives induding politics, economics, culture and so on, which has also transformed the education. With various online courses emerging at different kinds of websites, huge volumes of data of learners has been generated, from attendance rates to test scores, to track the learners comprehensively. Now, by Learning Analytics technology, many educational institutions use these data to analyze students' interests, performance and behavioral issues and then make a personalized plan accordingly, promoting the development of individual education. In China, little research has been done between Big Data and individual education, so this paper aims to show the opportunities and challenges created by the Big Data, put forward some coping strategies when facing the challenges and provide a reference for the other researchers to make a further study.
\end{abstract}

Keywords-Big Data; individual education; Learning Analytics; opportunities and challenges; coping strategies

\section{INTRODUCTION}

With the rapid development and popularity of emerging technologies such as the Internet, Cloud computing and Internet of Tings, the data storage capacity is increasing by leaps and bounds, along with the advent of Big Data. The government makes effective of the data to enhance comprehensive national power. For example, in March 2012,the White House announced The Big Data Research and Development Initiative, investing more than \$200 million to speed up the scientific discovery, strengthen homeland security and transform education [1]. The companies use data to optimize their products and service, finally increase the sales, such as shopping websites like Taobao, video websites like Youtube, and news websites like Sina all have developed Data Analys is System to collect information once the users signed in, that's why a user registration is always required by most sites. Companies can determine their customers' preferences, behaviors and habits, etc, through data analyzing, and recommend commodities that customers prefer to. Also, Matthew A. Waller, an A merican expert proposed DPB which supply chain management intersects with data science, predictive analytics, and big data among science and research, education and commercial areas [2].

The arrival of Big Data has inevitably brought innovation in the field of education. While in China, all of schools cultivate students by a uniform standard, ignoring individual difference, which, to some extent, is a kind of unfair education. With various online courses emerging in the age of Big Data, we can track the learners comprehensively through large amounts of data and analyze students' interests, performance and behavioral issues and then make a personalized plan accordingly, promoting the development of individual education [3]. So we have to size the chance to transform from standardized education to personalized education. There's still little research about this topic, so here I just want to arouse the attention and provide a reference for other researchers .

\section{DEFINITION OF CONCEPTS}

\section{A. What is Big Data?}

McKinsey, a consulting firm and the first one came up with "Big Data" in 2011, described Big Data as "large and complex datasets collected from digital and conventional sources that are not easily acquired, stored, managed or analyzed by traditional software" [4]. While Boyd and Crawford define Big Data as "a cultural, technological and scholarly phenomenon that rests on the interplay of : technology, analysis and mythology"[5]. Actually, Big Data is the collection of explosive information caused by the information technology, and the quantity is larger than the computer can handle. Big Data is "big", not the quantity, but the potential value.

McAffee and Brynjolfsson think there are three types of Big Data: volume, which refers to the number of information, easy to attain a terabyte; variety, which means the information includes texts, pictures, videos and GPS signals from cell phones, etc [6]; velocity, information can be processed in realtime through data analysis and data mining [7]. Some experts think it should add value and visualization [8], for Big Data has potential value for prediction and research, and visualize the results as well [9]. In addition, I guess we should also add personal packed-up information which named on my own, for Big Data is a corpus formed by each of the personal 
information, so this feature vividly embodies the source and composition of Big Data.

\section{B. What is Individual Education?}

When it comes to individual education, we tend to think of "teaching students according to their specific aptitude" proposed by Confucius, "one-to-one" education presented by extracurricular counselling and tutoring services, "personality education" said by psychologists and "reasonable matching" put forward by an American expert, Carol. However, all of these are unable to interpret today's individual education. Here, the "personalized" can refer to the variety of learning resource, the liberty to select curriculu m or to arrange the time and place to learn according to the learners [10]. Frankly speaking, under the help of information, we can make a personalized plan according to each student, and finally discover a kind of balance between personality and academic environment, which we consider as individual education [11].

\section{What is Learning Analytics?}

Learning Analytics (LA), derived from business intelligence and data mining [12], is widely used to measure, gather, analyze and report educational big data about learners and their contexts, for the purpose of understanding and optimizing learning and the surroundings in which it occurs [13]. The most important function is the monitoring and prediction, by which you can predict potential is sues and make corresponding intervention [14].

\section{THE OPPORTUNITIES AND CHALLENGES PRESENTED BY BIG DATA}

In the past, with the obstacles of tracking the learners, we couldn't adjust our learning strategy accordingly. Now, the emergency of online courses enable us to track and to collect all the data about learners. Especially with the maturity of Al, we can easily achieve our previous objective. It is the Big Data make it possible..

\section{A. Opportunities}

\section{1) For the government}

For the government, which include policy makers and agencies involved in educational affairs, Education policy will be made more scientifically through Big Data. In our traditional way of policy making, we always chose the methods of random sampling or panel discussion, or even depended on the preference of policy makers, which added more human intervention and fell into ideological bias [15]. But today, these policy makers can use big data collected across institutions to evaluate education on national and regional scales. They will acquire various types of data, such as characteristics of learner motivation to predict the direction and laws of education which may aid in making corresponding decisions for education, and a gift for individual education.

I still remembered when I attended the conference of IFET2015 (International Foru m on Educational Technology) in September, the vice-president of South China Normal University, You-Qun Ren, he showed us some preferential policies for students, who overemphasized some courses and cannot perform well in the college entrance examination .In other words, they have potential in some certain area. Theoretically, they wouldn't be admitted by the college without hitting the cutoff score. Instead, they all have been recruited for their genius. The university track them all the time even they were graduated, the data proved that they all have a better job and improve their living standard. So this is the proof that nobody can question it. This is the power of data. Therefore, we should make more resemble policies based on data.

\section{2) For school management}

In order to conform to the era of Big Data, the revolution of school is crucial. Firstly, the school has to construct the environment required by the Big Data, such as purchasing infrastructure, recruiting professional technicians to build the platform of online learning, or construct the virtual campus. After all these preparation, we will carry out personalized management through data analys is.

a) The management of teacher will be more equal and reasonable. When we hire a new teacher, we can learn all the he or her through data analysis to determine whether he/she is the best choice. And also we can make evaluation of teaching efficiency to judge the teachers with justice, so there won't be any discontent.

b) As for the management of students, we can predict the real-time study information about all subjects, and take credit warning in advance; we can examine the students' comprehensive quality and make some intervention on their deficiencies; we can even locate the students' position to make sure their security; otherwise, according to their online records, we can eliminate malicious information to protect their physical and psychological health. It is Big Data that meets the requirement of personalized development [16].

c) As for the management of educational teaching, the school can make the annual education plan with suitable characteristics through the data examination of teachers and students; and if we can make sure data sharing in the future, they can visit each other among schools, they can make the optimal management mode by learning, draw lessons from other schools [17].

\section{3) For tecahers}

a) Teachers can use the information technology to collect data about students' learning progress, acquisition and monitor their behavior; through Al, teachers will get the information about learning style, learning mode about every student, so personalized teaching scheme will be created; they can select courses and learning materials for each students and make responses as soon as possible [18]; likewise, they can evaluate the students more objective and more equal [19].

b) For teachers themselves, they will not be recognized as the only way to transfer knowledge, but like students, they can be the participants of personalized study. They can get make further education to enhance their own expertise.

c) Teacher can also carry on self-reflection through data of students' feedback. The objectivity of data will make teachers keep a sense of crisis, warning them that they have to 
adjust the teaching plan, once in a while, or they will lose their job.

\section{4) For stududents}

a) They will be transformed from passive learning to autonomous learning, large amounts of information enable them to make a choice. Textbook is no longer the only source of knowledge. As long as they have the motive, the passion, they can learn everything they want. And there will be provided with professional guidance, such as Personalized Adaptive Online Learning Analysis Model [20].

b) They will be transformed from one single learning mode to blending mode. Traditional classroom teaching style is no longer the only pattern, instead, there will be a fusion of different patterns and various modes. They can choose collective learning or autonomous learning, online learning or offline learning, lecture-type teaching or research-style teaching.

To sum up, all these four items are linked with one another, for teachers has to make adjustment according the students, schools depend on teachers and students, the government rely all the above three items. In turn, schools has to implement the policies made by government, teachers and students are under management of their school. Meanwhile, what we all have done is to make students develop better. So this has played as the safeguard for the personalized education.

\section{B. Challenges}

When Big Data brings the chances to individual education, there will inevitably bring the challenges simultaneously.

1) The challenge of privacy

Privacy is the first and most important challenge. Although what we mentioned is about personalized education, what we collect is not only about learning, but also involved our private information. Once the private information is exposed to the public, learners won't share any valuable data, on the contrary, they maybe offer false information deliberately. Definitely, this situation will affect the effectiveness of data and we have no idea what will happen.

Or even we have made comprehensive protection about privacy, we still have no insurance about the leakage. For example, the White House give the citizens more power to determine whether their data will be used by others [21], but some citizens don't want to read the Privacy Act or they have no ability to read because of language barrier.Then what should we do?

2) The challenge of data compatibility

If datasets are not in the same format [22], it may be difficult for researchers to read from one system to another. There will be created with messiness [23].

3) The challenge of Big Data Thinking

What is the most difficult is the change of our mind. How can we take advantage of millions of pieces of information? Some skills we have learned in the past are no longer fit for today, so we have to cultivate the Big Data thinking, as Schon professor and Mr Cook mentioned in their book, Big Data, Big
Data Thinking claim to consider all the world and all the staff as a platform to collect and share data [24].

\section{4) The challenge of digital gap}

In the era of Big Data, who owns data then he will be the winner. Just like the students of famous universities, they are available to much more excellent resources with the help of school's power and money. And they have access to get more big data learning system, of course, they will be superior to the other students in school, as well as their career. So this will aggravate the digital divide.

\section{COPING STRATEGIES}

\section{A. Privacy Legislation}

In the field of education, if you abuse the learning information without any moderation, you will lose the trust from students and parents, which is the only way to make sure the data effectively. So we have to create privacy legislation to protect private information. Such as make sure the data security; if it is unnecessary, try to collect the data anonymously; if you want to use the data, you have to obtain the permission from the owners; and even the client can ask for compensation fee accordingly. Well, what we have to do is to ensure the validity of data.

\section{B. Strengthen Technolgy}

In order to attain the individualized education, what we need is not only the hardware equipment, but also the high-tech to construct the environment, such as the platform of online learning, virtual community and student management system. So we have to boost the development of technology. Second, we have to choose a format as the standard to make sure the migration and sharing of data without barriers.

\section{Strengthen Technolgy}

The blossom and application of Big Data affect our mind in three aspects: thinking subjects, thinking objects and thinking medium. Whether it is the Facebook which provides personalized learning, or the East China Normal University which developed "Family economic difficulties students warning system", both of these manifest the Big Data thinking. It is critical for us to explore new technology and methods to seek more suitable clas sroom, teacher and campus [25].

\section{Strengthen Technolgy}

If Big Data will create new inequality and aggravate digital divide, then we have to guarantee policy implementation to make sure everyone can get the data. Just like purchasing goods, you can buy anything with money. On the other hand, we can improve the portability of data to get the data flowing. We don't have to operate data on some certain platform, so we can get rid of the bondage. We can use data anytime, anywhere. Big Data will be omnipresent [26].

\section{SUMMERY AND REFLECTION}

Individual education has always been the pursuit of our ideal education, well, Big Data has just brought this opportunity. Most people may think that we should size this 
chance to promote individual education, but is this really what we want? The individual education created by Big Data? We all have known that through Learning Analytics, our future will be designed in advance, such as our character, our personality, our career and so on, we don't have to make any decision. Is it really what you or me want? Or have you all ever thought that one day, we may suffer from the sick of data dependence? Or have you ever wondered different kinds of data may produce various voice, and data is just a natural number without human's as sistance[27]?

We are likely to be deceived by the age of Big Data, and ignore many details. Whenever, we have to keep calm and treat the situation objectively. What exactly does Big Data bring to us, whether it is an angel or a monster, further education is still needed. So I hope this article will provide a reference for other researchers.

\section{REFERENCES}

[1] Eve S. Mc Culloch, "Harnessing the Power of Big Data in Biological Research,” BioScience, vol.63, No.9, pp.715-716, September 2013.

[2] MA Waller and SE Fawcett, "Data Science, Predictive Analytics, and Big Data: A Revolution that will Transform Supply Chain Design and Management," Social Science Electronic,2013, vol. 34, No. 2, pp.77-84.

[3] [20]姜强. 基于大数据的个性化自适应在线学习分析模型及实现 [J]. 中 国电化教育, 2015 (336) : 85-92.

[4] Manyika. J, " Big data: The next frontier for innovation, competition, and productivity," http://www.mckinsey.com/insights/business_ technology/big_data_the_next_frontier_for_innova-tion,2011.

[5] D Boyd and K Crawford, "Critical Questions for Big Data: Provocations for a Cultural, Technological and Scholarly Phenomenon," Information Communication \& Society, 2012, vol. 15, No. 5, pp.662-79.

[6] MA Andrew and B Erik, "Big Data: the Management Revolution, Harvard Business Review,” 2012, vol. 90, No. 10, pp.60-68.

[7] 祝智庭. 基于大数据的教育技术研究新范式 $[\mathrm{J}]$. 电化教育研究, 2013(10): 5-13.
[8] E.Quinn, "The 6 Vs: The BI/Analytics Game Changes so Microsoft Changes Excel," http://www.esg-global.com/blogs/the-6-vs-thebianalytics-game-changes-so-microsoft-changes-excel/,2013.

[9] 袁旭. 大数据时代背景下大学生个性化教育探讨 [J]. 科教文汇 (下旬刊), 2015 (2) : 45-46.

[10] 刘少娟. 云课程:大数据时代下个性化教育的追求 [J]. 现代教育科学, 2015 (3) : 135-137

[11] 吴刚. 大数据时代的个性化教育: 策略与实践 $[\mathrm{J}]$. 南京社会科 学, 2015(7): 104-110.

[12] [18][22]Jacqueleen A. Reyes, "The skinny on big data in education:Learning analytics simplified," Tech Trends,2015, vol. 59, No. 2, pp.75-80.

[13] Siemens, G. "Learning and Knowledge Analytics -Kneut on -the fut ure of education?" http://www.learninganalytics.net/?p=126,2011.

[14] L.Johnson, R. Smith, H. Willis, A. Levine, K. Haywood. The 2011 Horizon Report. Austin, TX:The New Media Consortium[DB/OL]. http://net.educause.edu/ir/library/pdf/HR2011.pdf, 2013.

[15] 陈霜叶, 孟汶今, 张海燕. 大数据时代的教育政策证据: 以证据为本理念对 中国教育治理现代化与决策科学化的启示 $[\mathrm{J}]$. 全球教育展望, 2014 (2) : 121-128.

[16] B. Cope and M. Kalantzis. "Interpreting Evidence-ofLearning:Educational research in the era of big data," Open Review of Educational Research, 2015, vol. 2, No. 1, pp.218-239.

[17] 周湘林. 大数据时代的教育管理变革 [J]. 中国教育学刊, 2015 (10) : 25-30.

[19] Jyotsna T. W. "Discovering Big Data Modelling for Educational World," Procedia - Social and Behavioral Sciences,2015, No. 176, PP.642-649.

[21] Camelia CRI AN,Alexandra ZBUCHEA, and Steliana MORARU, “ Big Data: the beaut y or the beast," Strategica, 2014, pp. 829-849.

[23] W. Greller and H. Drachsler, "Translating learning into numbers: A generic framework for learning analytics," Internationnal forum of Educational Technology \& Society, 2012, vol. 15, No. 3, pp.42-57.

[24] [26] 赵中建, 张燕南. 与大数据同行的学习与教育-《大数据时代》作者 舍恩伯格教授和库克耶先生访谈 [J]. 全球教育展望 2014, 43 (12) : 3-9.

[25] 张燕南, 赵中建. 大数据时代思维方式对教育的启示 $[\mathrm{J}]$. 教育发展研 究, 2013, (21) : 1-5.

[27] 高书国. 大数据时代的数据困惑--教育研究的数据困境 $[\mathrm{J}]$. 教育科学研 究, 2015(1) :24-30. 